\title{
The use of bottom ash for replacing fine aggregate in concrete paving blocks
}

\author{
Antoni $^{1,}{ }^{,}$, Kevin Klarens ${ }^{1}$, Michael Indranata ${ }^{1}$, Luthfi Al Jamali ${ }^{2}$, and Djwantoro Hardjito ${ }^{1}$ \\ ${ }^{1}$ Civil Engineering Department, Petra Christian University, Surabaya, Indonesia \\ ${ }^{2}$ PT Jawa Power - YTL Jawa Timur, Probolinggo East Java, Indonesia
}

\begin{abstract}
Bottom ash that results from coal burning for electrical generation is still much underutilized in Indonesia and it is necessary to increase the usage of this waste. The manufacture of paving blocks using bottom ash, which is normally associated with high water absorption due to its high porosity and carbon content, was examined in this study with the aim to increase the usage of this waste material. The study was done in three phases: (1) the mixture of cement and bottom ash passing sieves of 2 and $5 \mathrm{~mm}$ were done with ratios of 1:3,1:4, and 1:5; from the best proportion, fly ash was used to replace the cement material from $10-80 \%$, and (3) samples with $30 \%$ and $50 \%$ fly ash replacement ratios were used in combination with $5 \mathrm{~mm}$ and $10 \mathrm{~mm}$ sieved bottom ash. Compressive strength, water absorption, and abrasion resistance tests were conducted to assess the properties of the resultant paving block. From the result, bottom ash is used to replace natural sand in making paving blocks. By optimizing the particle packing density and using fly ash as a cement replacement, the compressive strength of paving blocks can exceed $40 \mathrm{MPa}$.
\end{abstract}

\section{Introduction}

The production of concrete paving blocks requires natural resources that are difficult to renew. Sand availability is reducing with the more stringent environmental preservation act. In contrast, coal burning waste material from power plants has become an environmental problem. One power plant in East Java uses about 250 tons of coal each hour (2015 figures) and generates combustion waste of $4 \%$ and consisting of $25 \%$ bottom ash and $75 \%$ fly ash. The utilization of fly ash in construction is more common worldwide, reaching $47 \%$ of total fly ash produced; however, only $5.28 \%$ of bottom ash is used [1,2]. Thus, there is a need to utilize bottom ash to reduce waste deposits in ash ponds and reduce the use of natural sand [3-5].

The effort to utilize bottom ash is constrained by the distinctiveness of its grain shape. A very coarse particle shape facilitates interlocking between particles, causing a decrease in fresh mixed workability when bottom ash is utilized as a fine aggregate. However, bottom ash is a suitable material to substitute sand in a concrete mixture. The use of $100 \%$ bottom ash can be applied to concrete where the workability can be ignored, e.g., in the making of

\footnotetext{
*Corresponding author: djwantoro.h@petra.ac.id
} 
paving concrete [6,7]. Currently, the bottom ash of the power plant is only stockpiled in ash pond in plant location while almost $100 \%$ of the fly ash is used by various ready mix plants around East Java to make concrete.

This study tries to maximize the use of bottom ash as a substitute for all sand in producing concrete paving blocks. Maximizing the use of bottom ash was done by sieving separation to evaluate the effect of different particle sizes on the paving block's properties. Bottom ash paving block was made with the aim of achieving the compressive strength, water absorption, and abrasion resistance required by the Indonesian national standard [8]. Fly ash was used in the mixture to reduce cement consumption and increase the workability of the mixture [9]. The water required to obtain a workable mixture also was recorded as a basis for analyzing the resulted concrete.

\section{Experimental methods}

\subsection{Materials}

Fly ash and bottom ash are obtained from a power plant in Paiton, East Java, as the experiment was conducted near the power plant location. Results of the XRF test for fly ash and bottom ash are shown in Table 1 . The bottom ash used is classified by sieving at 2, 5, and $10 \mathrm{~mm}$ to obtain different particle gradations. The cement used was Portland Pozzolan Cement (PPC) from PT. Semen Gresik in a small cement bag. The sand for the control sample is sand passing a $5 \mathrm{~mm}$ sieve from Lumajang quarry, East Java. The bulk volume and the specific gravity of each material are shown in Table 2.

Table 1. Oxide compositions for fly ash and bottom ash from the XRF test

\begin{tabular}{|c|c|c|c|c|c|c|c|c|c|c|c|c|}
\hline Oxide & $\mathrm{SiO}_{2}$ & $\mathrm{Al}_{2} \mathrm{O}_{3}$ & $\mathrm{Fe}_{2} \mathrm{O}_{3}$ & $\mathrm{CaO}$ & $\mathrm{SO}_{3}$ & $\mathrm{MgO}$ & $\mathrm{TiO}_{2}$ & $\mathrm{~K}_{2} \mathrm{O}$ & $\mathrm{Na}_{2} \mathrm{O}$ & $\mathrm{MnO}_{2}$ & $\mathrm{P}_{2} \mathrm{O}_{5}$ & $\mathrm{LOI}$ \\
\hline Fly ash & 34.29 & 16.62 & 15.38 & 18.18 & 1.63 & 7.52 & 0.73 & 1.35 & 2.97 & 0.17 & 0.25 & 0.36 \\
\hline Bottom ash & 34.39 & 10.02 & 18.41 & 21.16 & 0.66 & 9.7 & 0.65 & 0.9 & 0.24 & 0.22 & - & 3.54 \\
\hline
\end{tabular}

Table 2. Bulk volume and specific gravity of the material

\begin{tabular}{|c|c|c|}
\hline Material & $\begin{array}{c}\text { Bulk Volume } \\
\mathrm{kg} / \mathrm{m}^{3}\end{array}$ & $\begin{array}{c}\text { Specific } \\
\text { Gravity }\end{array}$ \\
\hline Bottom ash (passing $5 \mathrm{~mm}$ ) & 1382 & 2.26 \\
\hline Bottom ash (passing $2 \mathrm{~mm}$ ) & 1328 & 2.33 \\
\hline Sand & 1598 & 2.72 \\
\hline Cement & 1181 & 3.05 \\
\hline Fly ash & 1276 & 2.75 \\
\hline
\end{tabular}

\subsection{Specimen preparation and test}

The study was done in three phases. Phase 1 aims to understand the normal paving block mixture by varying the aggregate to cement ratio and a mixture using two sizes of the bottom ash. Phase 2 started with the best result of phase 1 and used fly ash to replace the cement material from $10-80 \%$. At phase 3, the samples with $30 \%$ and $50 \%$ fly ash replacement ratio were used in combination with $5 \mathrm{~mm}$ and $10 \mathrm{~mm}$ sieved bottom ash to increase the density of the matrix. Table 3 shows the detailed mix proportion.

The paving block was made using a semi-automatic mixer and hydraulic press former. The procedure for mixing is as follows. Cement was poured into the mixer and the bottom ash follows in dry condition. If fly ash is used, then fly ash is poured in first followed by 
cement. Water is added to the mixer sequentially until the desired condition is achieved. The desired mixture is when the wet mixture is clasped and kneaded the mixture remains as a form as shown in Figure 1; that is, the mixture would not crumble after compaction. The mixture then was formed into paving blocks by using hydraulic pressure and vibration. Tests conducted were for compressive strength ( $7,14,28$ days), water absorption (28 days), and abrasion resistance (28 days). The targeted properties are "Grade A" based on the Indonesian Standard as shown in Table 4.

Table 3. Mixture proportion for the three phases

\begin{tabular}{|c|c|c|c|c|c|c|c|c|c|c|c|}
\hline No & Code & $\mathbf{C}$ & BA & Sand & Description & No & Code & C & FA & BA & Description \\
\hline \multicolumn{6}{|c|}{ Phase 1 } & \multicolumn{6}{|c|}{\begin{tabular}{|l|} 
Phase 2 \\
Pa
\end{tabular}} \\
\hline 1 & C1S3 & 1 & - & 3 & \multirow{6}{*}{$\begin{array}{l}\text { River sand } \\
\text { for control } \\
\text { (C-S) }\end{array}$} & 1 & C9F1-B30-5 & 0.9 & 0.1 & 3 & \multirow{8}{*}{$\begin{array}{c}\text { Fly ash replacing } \\
\text { cement with } 5 \\
\text { mm bottom ash } \\
\text { material and } 1: 3 \\
\text { binder to aggr. } \\
\text { ratio } \\
\text { (CF-B) }\end{array}$} \\
\hline 2 & C1S4 & 1 & - & 4 & & 2 & C8F2-B30-5 & 0.8 & 0.2 & 3 & \\
\hline 3 & C1S5 & 1 & - & 5 & & 3 & C7F3-B30-5 & 0.7 & 0.3 & 3 & \\
\hline 4 & C1S6 & 1 & - & 6 & & 4 & C6F4- & 0.6 & 0.4 & 3 & \\
\hline 5 & C1S7 & 1 & - & 7 & & 5 & $\mathrm{C} 5 \mathrm{~F} 5$ & 0.5 & 0.5 & 3 & \\
\hline 6 & C1S9 & 1 & - & 9 & & 6 & $330-5$ & 0.4 & 0.6 & 3 & \\
\hline 7 & C1B3-2 & 1 & 3 & - & \multirow{3}{*}{$\begin{array}{c}\text { Bottom ash } \\
\text { passing } 2 \mathrm{~mm} \\
\text { sieve (C-B) }\end{array}$} & 7 & C3F7-B30-5 & 0.3 & 0.7 & 3 & \\
\hline 8 & C1B4-2 & 1 & 4 & - & & 8 & C2F8-B30-5 & 0.2 & 0.8 & 3 & \\
\hline 9 & C1B5-2 & 1 & 5 & - & & \multicolumn{6}{|c|}{$\mid$ Phase 3 } \\
\hline 10 & C1B3-5 & 1 & 3 & - & \multirow{3}{*}{\begin{tabular}{|c|} 
bottom ash \\
passing $5 \mathrm{~mm}$ \\
sieve (C-B)
\end{tabular}} & $\mid$\begin{tabular}{||l}
$\mid$ \\
1
\end{tabular} & $\mathrm{C} 7 \mathrm{~F} 3-\mathrm{B} 30 \mathrm{~K}$ & 0.7 & 0.3 & 3 & \multirow{3}{*}{$\begin{array}{c}\text { Combined size } 10 \\
\mathrm{~mm} \text { and } 5 \mathrm{~mm} \\
1: 1(\mathrm{CF}-\mathrm{BK})\end{array}$} \\
\hline 11 & C1B4-5 & 1 & 4 & - & & 2 & C5F5-B30K & 0.5 & 0.5 & 3 & \\
\hline 12 & C1B5-5 & 1 & 5 & - & & & & & & & \\
\hline
\end{tabular}

Table 4. Classification of paving block grades according to SNI 03-0691-1996 [8]

\begin{tabular}{|c|l|c|c|c|c|c|}
\hline \multirow{2}{*}{ Grade } & \multirow{2}{*}{ Usage } & \multicolumn{2}{|c|}{$\begin{array}{c}\text { Compressive } \\
\text { Strength (MPa) }\end{array}$} & \multicolumn{2}{c|}{$\begin{array}{c}\text { Abrasion Resistance } \\
\text { (mm/minute) }\end{array}$} & $\begin{array}{c}\text { Water } \\
\text { Absorption } \\
(\%)\end{array}$ \\
\cline { 3 - 6 } & & Average & Min & Average & Max & $(17$ \\
\hline A & Road & 40 & 35 & 0.090 & 0.103 & 3 \\
\hline B & Parking & 20 & 17 & 0.130 & 0.149 & 6 \\
\hline C & Walkway & 15 & 12.5 & 0.160 & 0.184 & 8 \\
\hline D & Garden & 10 & 8.5 & 0.219 & 0.251 & 10 \\
\hline
\end{tabular}
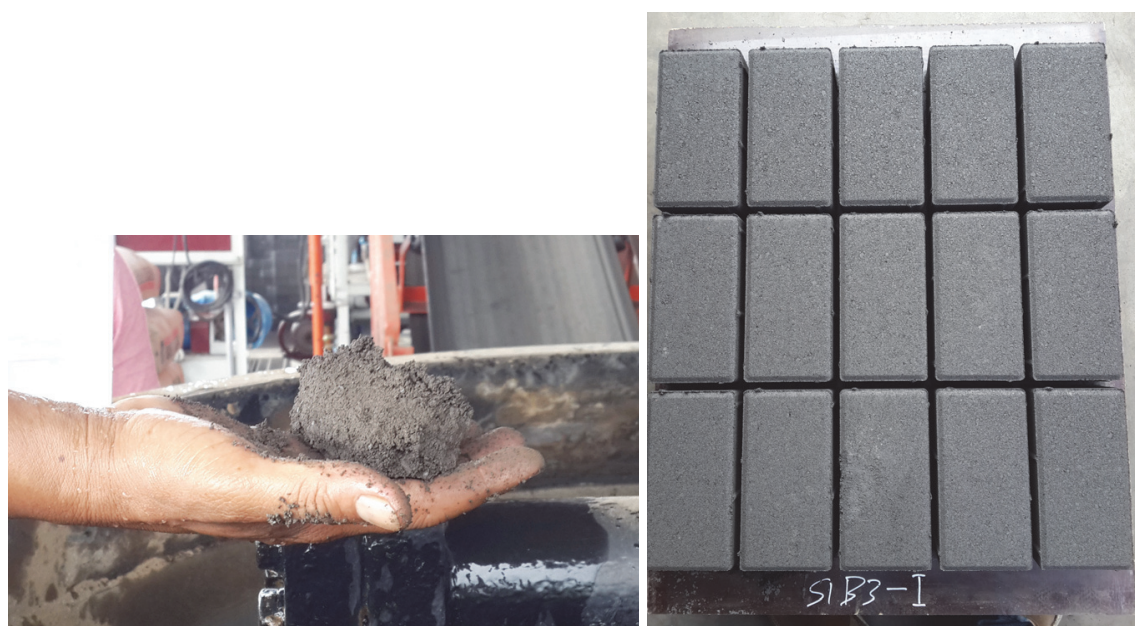

Fig. 1. Water required to make a stiff mixture and the paving specimens produced. 


\section{Results and discussion}

\subsection{Water requirement for paving block mixture}

The amount of water required for making a stiff mixture was determined for each mix and the water/solid ratio was calculated as the weight of water to combined weight of cementitious and filler. In phase 1, for paving block C-S series, there was no increase in water requirement with the increase of sand content (Figure 2(a)). The water demand was about the same for the mixture when more sand was used in the mixture. The reduction of the water to cement ratio is obvious with the reduction in the cement content as this would influence the compressive strength. When replacing sand with bottom ash aggregate (C-B), the water requirement was nearly doubled that required with the sand specimen. This shows that a change of material changes the water requirement significantly. There was a small increment with the higher aggregate ratio; however, the particle size did not seem to influence the water requirement. The average water to solid ratio of cement and sand was only 0.086 while the use of bottom ash only increased it to 0.182 .

The water requirements of phases 2 and 3 are shown in Figure 2(b). When replacing the cement with fly ash (CF-B), there was a reduction of water requirement as replacing more fly ash into the mixture reduces the water requirement because the round particle of fly ash acts as filler in the concrete mix. A significant decrease of water requirement began to be seen in the use of fly ash above $50 \%$ of cement replacement. The average water/solid ratio of CF-B is 0.161 , showing that replacement by fly ash would benefit the mixture condition.

Phase 3 shows a significant reduction in the water requirement when aggregate gradation is changed (CF-BK), resulting in a water/solid ratio lower than the other mixture that used bottom ash (0.110). Figure 2(b) also shows that with a higher fly ash replacement ratio, the water to cementitious ratio was reduced.
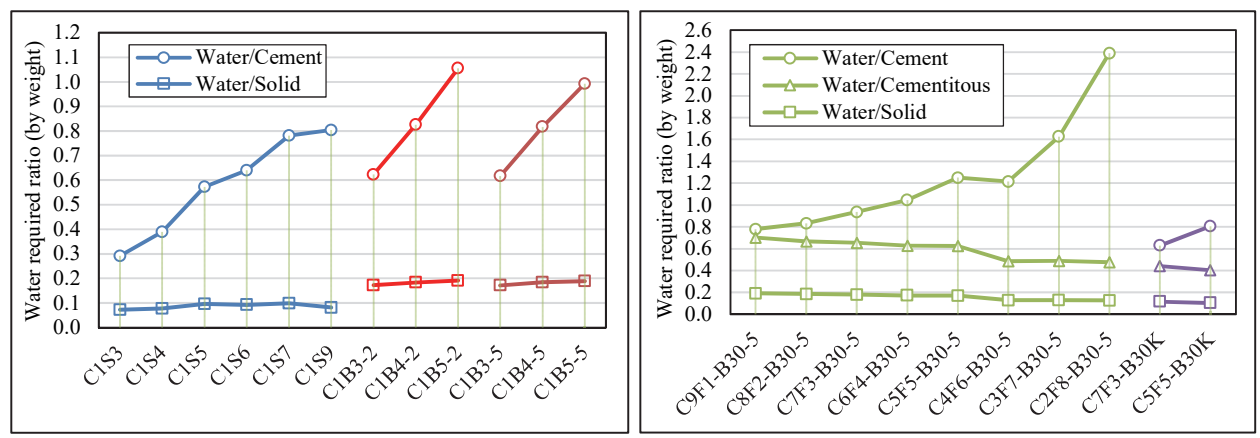

Fig. 2. Water required for making a stiff mixture (a) phase 1 and (b) phases 2 and 3.

\subsection{Physical properties of the paving block}

\subsubsection{Compressive strength}

The compressive strength of all paving samples increases with age. Figure 3 shows the compressive strength for all specimens at 7, 14 and 28 days. For the C-S series, the more sand added the lower the strength. Paving made with bottom ash passing a $5 \mathrm{~mm}$ sieve has a compressive strength better than that of the $2 \mathrm{~mm}$ ash, which is most likely due to less surface area with larger particle size. 
For the CF-B series, the cement replacement with fly ash decreased the compressive strength of the paving due to lower hydrate volume. Samples with $20-50 \%$ fly ash replacement have about the same compressive strength; however, the strength decreases with a higher replacement ratio.

The compressive strength of paving increased significantly (i.e., above $40 \mathrm{MPa}$ ) in all phase 3 samples, where the aggregate was a mixture of $50 \%$ bottom ash (CF-BK) passing a $10 \mathrm{~mm}$ sieve and $50 \%$ passing a $5 \mathrm{~mm}$ sieve. This showed that the use of the right combination of bottom ash gradations increases the packing density of the paving blocks and, thus, increases their compressive strength. From the compressive strength, it was found that both phase 3 mixtures could achieve Grade A quality as specified by the standard.
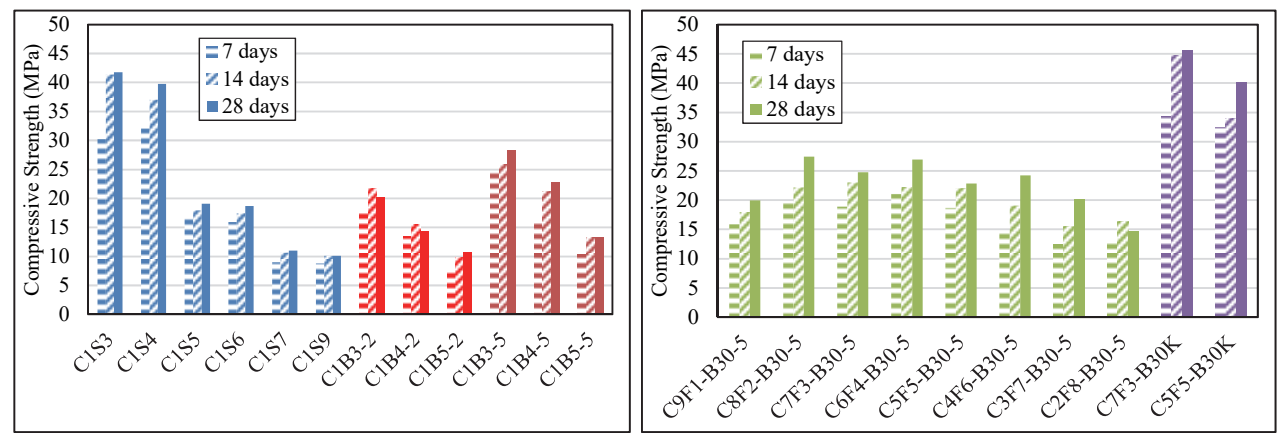

Fig. 3. Compressive strength at 7, 14 and 28 days for (a) phase 1 and (b) phases 2 and 3.

The relationship of the compressive strength water to cementitious ratio is shown in Figure 4(a). The inverse relationship of water to cementitious ratio follows the norm that the lower water to cementitious ratio would have the higher compressive strength. The effort in increasing the compressive strength should focus on reducing the water required by better controlling the gradation of the aggregate. Figure 4(b) shows the relationship of compressive strength and bulk density of the paving block. The CF-BK series had higher bulk volume due to better gradation control, hence, obtaining higher bulk density. The C-S series shows a higher density because the sand's specific gravity is higher than that of the bottom ash.
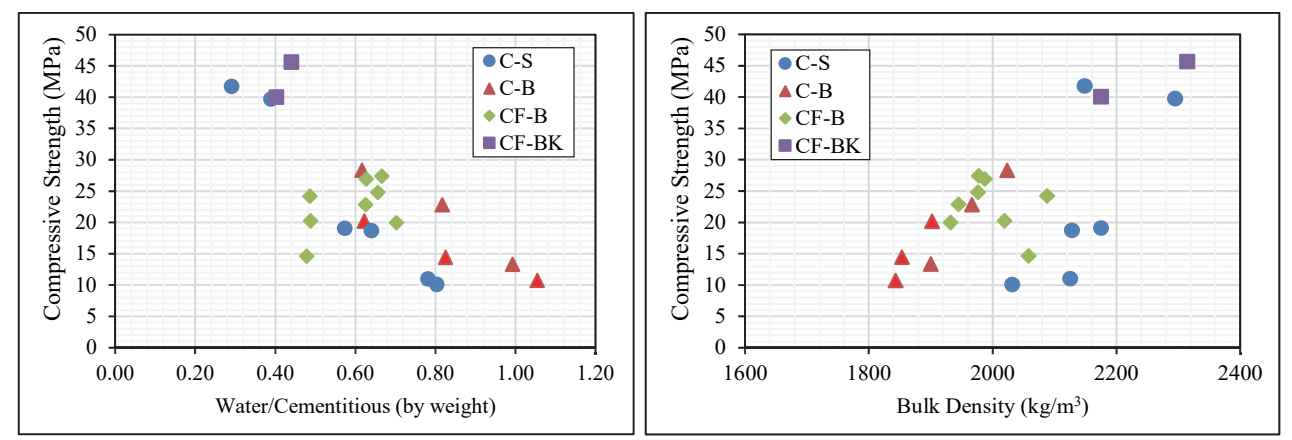

Fig. 4. Relationship of compressive strength of the sample with (a) water to cementitious ratio and (b) bulk density of the sample. 


\subsubsection{Water absorption}

High water absorption adversely affects the durability of paving. The result of water absorbance tests at 28 days can be seen in Figure 5. From phase 1, paving block C-B series with $5 \mathrm{~mm}$ bottom ash size has a lower water absorption than the one with $2 \mathrm{~mm}$ size. This is due to more uniform particle sizes of bottom ash passing a $2 \mathrm{~mm}$ sieve, resulting in more void.

The figure also shows that the use of fly ash as a cement replacement material increases water absorption; however, the higher fly ash content did not have any significant impact on the increment. The CF-BK mixture was shown to be the only mixture with less than $3 \%$ water absorption even compared with the sand specimen. The bulk density of the specimen can be an indication of the water absorption rate as higher density results in a lower water absorption ratio.

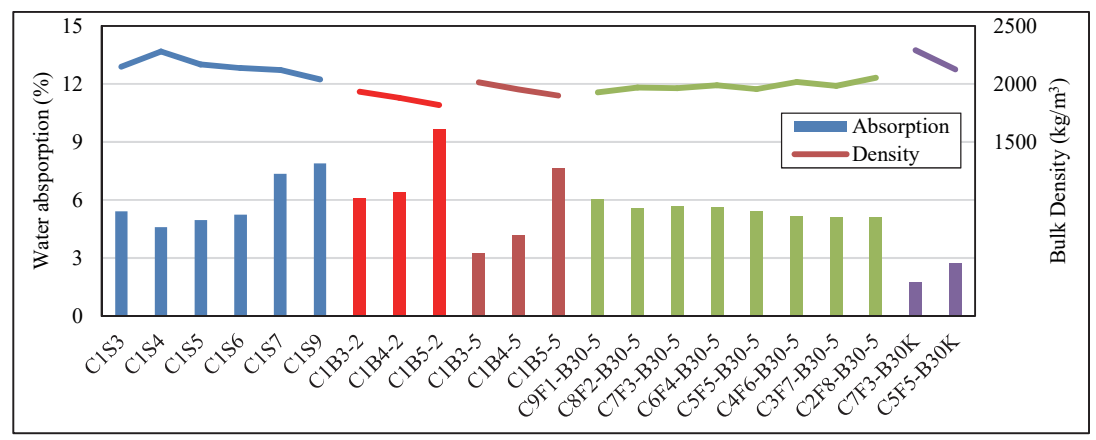

Fig. 5. Water absorption of the paving block sample in relation to its bulk density.

\subsubsection{Abrasion resistance}

The results from the abrasion resistance tests are shown in Figure 6. All mixtures here perform well under the standard specification of grade A. Mixture C1P3, which uses sand as the aggregate, has the highest abrasion resistance compared with $\mathrm{C} 1 \mathrm{~B} 3-5$, which has a wear value of $0.0239 \mathrm{~mm} / \mathrm{min}$. The use of fly ash as a cement replacement material resulted in reduced abrasion resistance. This means that a high fly ash replacement ratio lowers resistance to abrasion as the strength is also reducing with the increase of replacement ratio. Once again, the gradation combinations of bottom ash aggregate (C7F3-B30K and C5F5$\mathrm{B} 30 \mathrm{~K})$ have the highest abrasion resistance, which is comparable with the control specimen using sand only. Higher compressive strength contributes the abrasion resistance value, but it is also influenced by the type of binder used.

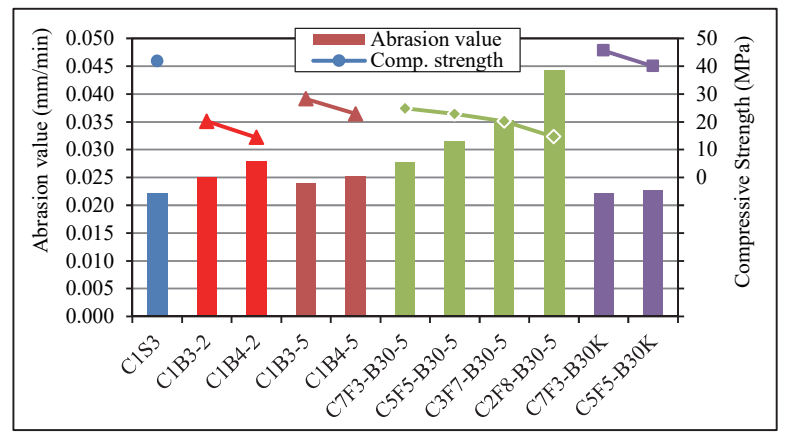

Fig. 6. Abrasion resistance of selected samples and their 28-day compressive strength. 


\section{Conclusions}

From the experimental study, several conclusions can be obtained.

1. Bottom ash can be used as a replacement for $100 \%$ sand in making concrete paving blocks. Bottom ash with a size combination of 50\% passing sieve $5 \mathrm{~mm}$ and $50 \%$ passing sieve $10 \mathrm{~mm}$ produces optimum mix composition. With $50 \%$ fly ash as a cement replacement, the resulting specimens have a compressive strength of $40 \mathrm{MPa}$ at 28 days.

2. The water requirement for making a stiff concrete mixture is more affected by the type of material used than its composition. It is important to use the lowest water requirement so that the mixture has the lowest water to cementitious ratio in order to obtain a higher compressive strength.

3. Using bottom ash increases water requirements compared with the control sand; however, mixing bottom ash passing a $10 \mathrm{~mm}$ and $5 \mathrm{~mm}$ sieve reduces the water requirements. This indicates that by combining different particle sizes the porosity can be reduced.

4. Water absorption in most of the mixtures was higher than $3 \%$. However, mixing $50 \%$ $10 \mathrm{~mm}$ and $50 \% 5 \mathrm{~mm}$ bottom ash yields specimens with water absorption below $3 \%$, thus, they can be classified as Grade A, as per target of the paving block quality.

5. Abrasion wear resistance is proportional to the compressive strength of the specimen and the hardness of the aggregate. All paving specimens can achieve a Grade A standard using a combination of bottom ash sizes..

6. From the results, it is suggested that the use of bottom ash can be increased to make high-quality paving blocks and reduce environmental loads due to unused bottom ash deposits. Properties that need to be considered for the use of bottom ash in large quantities include LOI values, size and gradation variations, and the level of porosity of the existing bottom ash.

Acknowledgment to PT. Jawa Power for providing the fly ash, bottom ash and the paving block equipment for the experimental study under the MOU number 002/MoU/FTSP/UKP/2015YTLJT/LTR/2015/00734.

\section{References}

1. H. Kurama \& M Kaya, Constr Build Mater, 22, 1922-1928 (2008)

2. S. Naganathan, A.Y.O. Mohamed \& K.N. Mustapha, Constr Build Mater, 96, 576-580 (2015)

3. S. Mengxiao, W. Qiang \& Z. Zhikai, Constr Build Mater, 98 (2015)

4. M. Singh \& R. Siddique, J Clean Prod, 91, 269-278 (2015)

5. N. Chousidis, E. Rakanta, I. Ioannou, \& G. Batis, Constr Build Mater, 101 (2015)

6. M. Singh \& R. Siddique, J Clean Prod, 112, 620-630 (2015)

7. H.-K. Kim, Constr Build Mater, 91 (2015)

8. Badan Standarisasi Nasional. SNI 03-0691-1996 Bata Beton (Paving Block) (1996)

9. Antoni, V. Satrya \& D. Hardjito, Civ Eng Dim, 17(1), 38-43 (2015) 